РОЗКРИТТЯ ПОНЯТТЯ ЖАДІБНОСТІ ЯК СОЦАЛЬНО-ПСИХОЛОГІЧНОГО ФЕНОМЕНА

\author{
DISCLOSURE THE CONCEPT OF GREED \\ AS A PSYCHOSOCIAL PHENOMENON
}

УДК 159.923.2

DOI https://doi.org/10.32843/2663-

5208.2020.14.22

\section{Шебанова В.І.}

д.психол.н.,

професор кафедри практичної

психології

Херсонський державний університет

\section{Іванова В.Д.}

студентка IV курсу соціально-

психологічного фракультету

Херсонський державний університет у статті розглядається «жадібність» як соціально-психологічний феномен. Для вирішення поставлених завдань були використані теоретичні методи дослідження: аналіз психологічної та фрілософрської літератури, класифрікація $і$ систематизація наукових джерел й емпіричних положень; емпіричні: авторська анкета «Дослідження уявлень про жадібність як особистісну рису». Дослідження проводилось на вибіриі осіб юнацького та зрілого віку. У результаті встановлено, що респонденти обох вікових груп визначають жадібність як небажання ділитися чимось або втратити щось уже наявне та пов'язують її із невпевненістю у собі та у завтрашньому дні. При цьому досліджувані юнацького віку пов'язують жадібність із досягненням власного задоволення будь-якими шляхами, незважаючи на оцінку оточуючих. Виявлено, що жадібність, як риса характеру людини, тісно пов'язана з їі емоційною сферою та власним ставленням до оцінки якості життя. Досліджено, що, на думку респондентів обох вікових груп, жадібність формують такі фрактори, як: виховання, невпевненість у собі, життєвий досвід, бідність та економічний стан країни. При цьому, на думку осіб юнацького віку, на формування жадібності ще впливає самотність людини та особистісні риси, такі як: завищена самооцінка, егоцентризм, самолюбство. Респонденти зрілого віку відносять до сракторів, що детермінують жадібність, обмеження у дитинстві. Виявлено, що респонденти зрілого віку знецінюють необхідність жадібності та оиінюють ії як негативну рису особистості як у власних проявах, так і у проявах інших. Для осіб юнацького віку жадібність є ресурсом, інструментом у встановленні власних кордонів задля задоволення власних потреб. Узагальнено, що серед сімейних послань у групі юнацького віку виявлені такі, що спрямовують їх на задоволення власних потреб і бажань, а також легке витрачання грошей, на відміну від послань осіб групи зрілого віку, акцент яких спрямований на задоволення потреб інших - рідних для них людей. Встановлено, що досліджувані оцінюють поняття «жадібність» із негативним емоційним навантаженням і частіше під час прояву жадібності відчувають: сором, незадоволеність собою, провину, злість на себе і вважають, що цю рису необхідно корегувати.
Ключові слова: жадібність, юнацький вік, зрілий вік, уявлення про жадібність, фрактори формування жадібності, ресурси.

The article considers greed as a socio-psychological phenomenon. There were used theoretical methods of research to achieve the goals and tasks: analysis of philosophical, psychological literature, classification and systematization of scientific literature, comparison, generalization of theoretical and experimental regulations. Author's questionnaire "The study of perceptions of greed as a personality trait" was created for empirical method.

We did a research study among persons of youthful and middle age. As a result, we found that people of both ages defined greed as a reluctance to share something or lose something they already had. Adolescents associate greed with achieving self-satisfaction in any way, regardless of the evaluation of others. It is revealed that greed as a human personality trait is closely connected with the emotional sphere and their own attitude to the assessment of quality of life. The result identified that the common factors in both groups of respondents that form greed are education, life experience, lack of self-confidence and economic situation of the country. At the same time, according to young people, the formation of greed is still influenced by human loneliness and personality traits, such as: overestimated self-esteem, egocentrism, selfishness. Adult respondents refer to the factors that determine the greed of restraint in childhood. It was found that adult respondents devalue the need for greed and evaluate it as a negative personality trait, both in their own manifestations and in the manifestations of others. For young people, greed is a resource, a tool in setting their own boundaries to meet their own needs. It was found that adult respondents devalue the need for greed and evaluate it as a negative personality trait, both in their own manifestations and in the manifestations of others. For young people, greed is a resource, a tool in setting their own boundaries to meet their own needs. It has also been found that the test subjects assess the concept of "greed" with negative emotional stress and often during the showing of greed they feel shame, dissatisfaction, guilt, anger on themselves and think that this quality should be corrected.

Key words: greed and the factors of greed, middle age, youth age, idea of greed, resource.
Постановка проблеми. Для сучасного українського суспільства характерні довготривалі трансформації соціально-економічного середовища, які зумовлюють зміни особистісних потреб, інтересів та життєвих стандартів. Необхідність ефективно розподіляти власні як матеріальні, так і нематеріальні ресурси може зумовлювати формування нових якостей характеру. Ми поділяємо думку С.Г. Яновської, Р.Л. Туренко, Н.С. Білоус, С.М. Криворучко, Р.А. Лютенко стосовно того, що ситуації невизначеності та дефіциту можуть детермінувати прояви скупості, алчності та формувати таку рису характеру, як жадібність [7, с. 55]. 
Аналіз останніх досліджень і публікацій, у яких висвітлена загальна характеристика поняття «жадібність», дав змогу нам узагальнити, що, незважаючи на те, що дослідники надають різне визначення цього поняття, їх семантичний зміст $€$ близьким один до одного. Зокрема, за психологічним словником B.I. Войтика синонімами до жадібності є: скупий, ненаситний, спраглий, алчний, економний [2]. Натепер науковці виокремлюють різні чинники, що зумовлюють формування та прояви жадібності. Однак фундаторами з цієї проблематики серед зарубіжних учених вважають дослідників психоаналітичного напряму. Так, 3. Фройд стверджував, що жадібність разом з охайністю та впертістю формується у разі фіксації на анальній стадії розвитку особистості, а отже, така людина схильна до накопичення різноманітних матеріальних або нематеріальних благ і неохоче їх витрачає [9]. Е. Фромм розглядав жадібність як якість особистості, яка є деструктивним продуктом соціуму. Саме тому за його теорією жадібність $є$ наслідком впливу соціальних умов, в яких формується особистість, і тому притаманна кожній людині більшою чи меншою мірою [3].

Згідно з теорією К. Хорні, жадібність визначається як інфантильне відчуття того, що завжди потрібно більше якихось благ: їжі, грошей, уваги, любові тощо. При цьому найголовніше - наявність відчуття, що ніхто у світі не збирається надавати те, чого не вистачає, або те, що потрібно [4]. Розвиваючи зазначені ідеї К. Хорні, дослідниця С. Ахтар відзначає, що якщо імпульси жадібності є усвідомлюваними і відповідно керованими, то вони можуть виступати потужними мотиваторами діяльності та досягнення цілей [8].

Таким чином, на основі вищезазначеного жадібність як риса особистості визначається як прагнення отримати все більше благ і нездатність легко витрачати вже накопичене, навіть на власні потреби. Аналіз літератури психологічного та економічного характеру дає змогу нам стверджувати, що жадібність переважно розглядається у зв'язку зі ставленням до грошей і таким поняттям, як економічна поведінка. Основою мотивації економічної поведінки людини переважно є прагнення отримати максимальну винагороду за рахунок мінімізації витрат [1]. Дослідниками в галузі економічної психології відзначено, що у людей ставлення до грошей залежить від низки факторів: статі, віку, соціального статусу, матеріального становища тощо. На думку Ю.В. Щербатих у суспільстві виокремлюються різні стилі здобування грошей та їх витрат. Наведемо стислу характеристику цих стилів: алчність - виразне прагнення людини до збагачення якомога більше; скупість - виявляється у бажанні не віддавати нічого із того, що вже має людина; власне сама жадібність, тобто жага отримувати якомога більше, яка сполучається із бажанням і віддавати якомога менше; «широта розмаху», а саме прагнення отримувати більше, аби потім вкласти ці кошти у нові власні проєкти; розрахунковість (бережливість, економність) - гроші витрачаються тільки на життєво необхідні речі у цей момент часу; щедрість, а саме легкість у витраті особистих коштів для допомоги іншим людям; марнотратство, тобто невміння накопичувати кошти, нерозумне, даремне витрачання грошей, майна [6].

У наших попередніх дослідженнях ми зауважували, що жадібність може виявлятися не лише у ставленні людини до грошей, але й стосовно їжі, власних речей, людей, проявів почуттів, емоцій, уваги, власних ресурсів тощо [5].

Однак натепер у дослідженні феномена жадібності залишаються невирішеними ще різні аспекти, зокрема уявлення про жадібність як соціальний феномен, що і зумовило написання цієї статті.

Постановка завдання. Метою нашого дослідження було теоретико-емпіричне дослідження психологічних особливостей прояву жадібності як соціального феномена. Завдання дослідження: 1) на основі теоретичного аналізу наукової літератури узагальнити інформацію з проблеми дослідження; 2) емпірично дослідити уявлення про жадібність як соціальний феномен. Методи та методики дослідження: спираючись на дані теоретичного обґрунтування з нашої проблематики, нами був застосований метод контент-аналізу для виокремлення смислових категорій і 3'ясування ставлення досліджуваних груп до поняття «жадібність», жадібної людини та необхідності цієї риси у житті. Емпірична вибірка дослідження: 60 студентів Херсонського державного університету двох вікових груп. Група 1: 30 осіб юнацького віку, студенти 1-5 курсів спеціальності 053 «Психологія», середній вік 20 років. Група 2: 30 осіб зрілого віку, студенти 3-5 курсів заочної форми навчання, середній вік - 36 років. Теоретичний аналіз сучасних наукових джерел дав змогу нам визначити науковий базис, на який ми спиралися у подальшому у розробці власної анкети. У цій роботі ми презентуємо аналіз саме тих запитань, які $\epsilon$ найбільш вагомі у розкритті теми роботи.

Виклад основного матеріалу. Для розкриття соціального феномена «жадібність» за авторською анкетою ми досліджували загальні уявлення респондентів щодо цієї риси. Результати презентовано нижче за окремими питаннями анкети.

У дослідженні нас цікавила думка респондентів щодо факторів, які можуть сформувати цю якість. Розподіл варіантів відповідей можна побачити на рисунку 1. 
Порівнюючи відповіді двох вікових груп досліджуваних, можна узагальнити, що респонденти обох вікових груп вважають, що факторами формування жадібності у людини є: виховання; бідність; невпевненість у собі; життєвий досвід; економічний стан країни. Різниця у відповідях полягає у тому, що, на думку осіб юнацького віку, на формування жадібно- сті ще впливає самотність людини та особистісні риси, такі як: завищена самооцінка, егоцентризм, самолюбство. Респонденти зрілого віку відносять до факторів, що детермінують жадібність, обмеження у дитинстві.

Отримані нами результати знаходять своє підтвердження у інших наукових працях (О. Дейнека, С.Г. Яновська, Р.Л. Туренко,

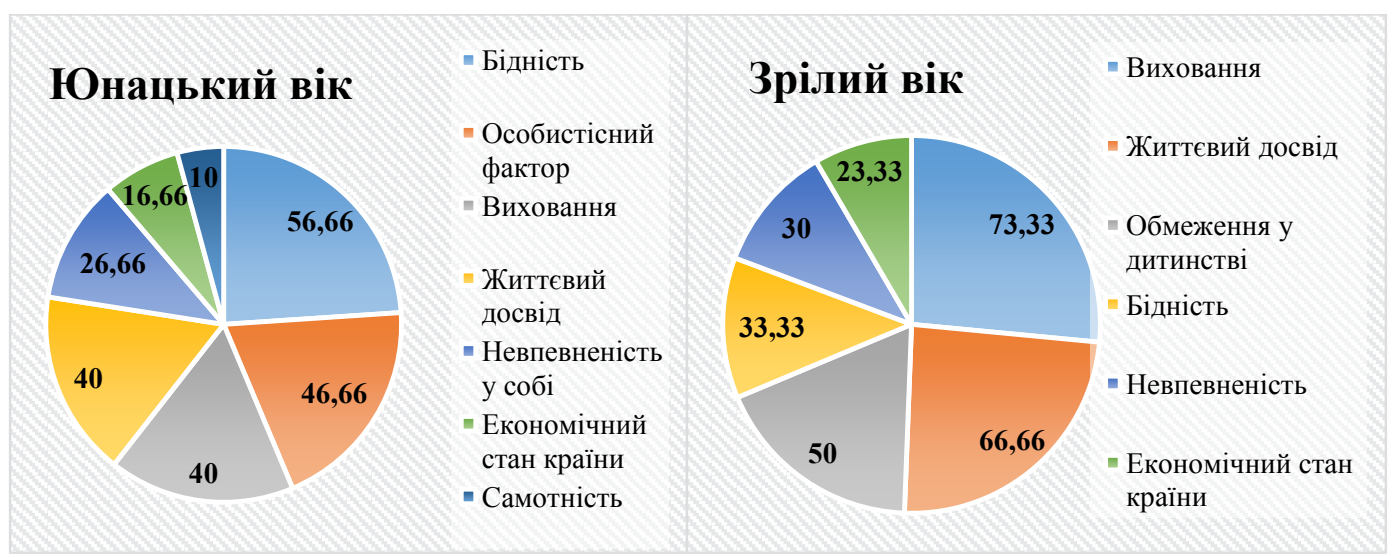

Рис. 1. Розподіл відповідей у досліджуваних груп респондентів щодо факторів, які формують жадібність

\section{Юнацький вік}

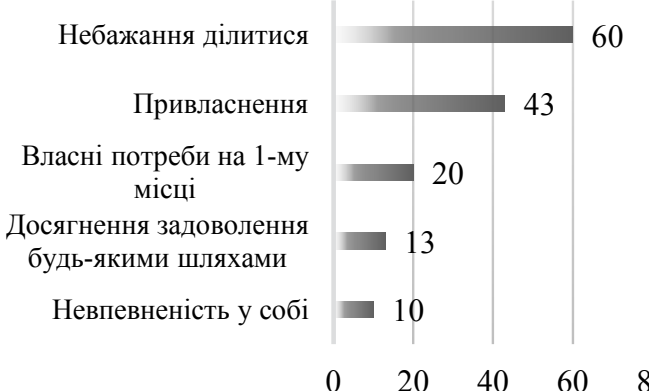

\section{Зрілий вік}

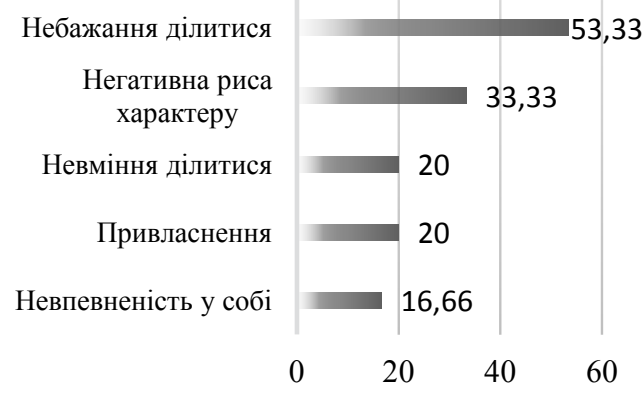

Рис. 2. Розподіл варіантів відповідей у досліджуваних груп респондентів щодо визначення жадібності

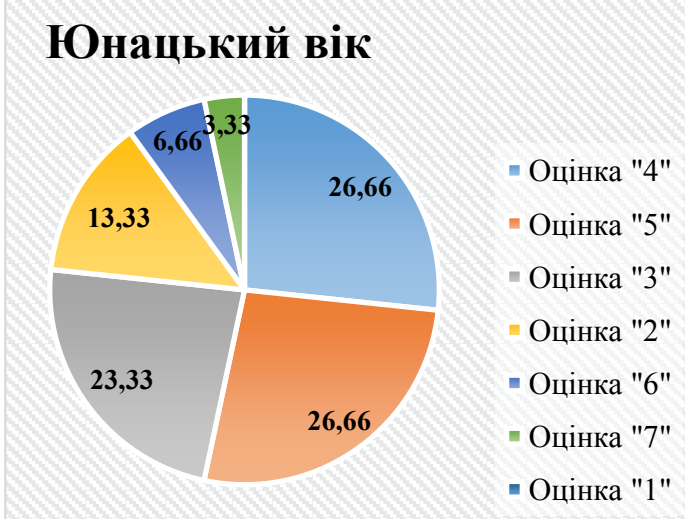

Зрілий вік

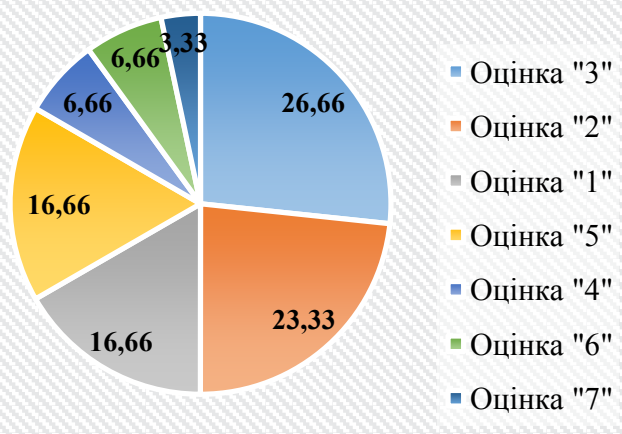

Рис. 3. Розподіл відповідей досліджуваних груп респондентів щодо оцінки необхідності жадібності як риси особистості у житті 
Н.С. Білоус, С.М. Криворучко, Р.А. Лютенко та ін.) Зокрема, С.Л. Рубінштейн зазначав, що важливим для людини $є$ задоволення власних потреб, а одним із факторів формування жадібності $€$ вплив сімейно-рольової пам'яті, яка транслюється через виховання, сімейні цінності та досвід попередніх поколінь, отриманий у минулому. Задоволеність життям досягається через упевненість у власній матеріальній стабільності та економічній стабільності країни [10].

Наступним у дослідженні було загальне з'ясування особливостей уявлення кожного з учасників щодо поняття «жадібність». Розподіл варіантів відповідей графічно подано на рисунку 2.

Як видно з рис. 2, загальним у респондентів юнацького та зрілого віку $€$ визначення жадібності як небажання ділитися чимось або втратити щось вже наявне; привласнення собі чогось; наявність невпевненості у собі, у завтрашньому дні.

Різницею є те, що в юнацькому віці жадібність більшою мірою пов'язують із досягненням власного задоволення будь-якими шляхами, незважаючи на оцінку оточуючих. Ми вважаємо, що отримані результати можна пояснити тим, що юнацький вік характеризується максималізмом, який проявляється у надмірній категоричності суджень, завищених вимогах до себе і частіше до інших людей, а також має спільні риси з егоїзмом.
Водночас люди зрілого віку вважають, що жадібність $є$ негативною рисою характеру, яка заважає у різних аспектах повсякденного життя людини, а особливо у налагодженні теплих та приємних зв'язків з оточенням. На нашу думку, це пов'язане із тим, що на цьому життєвому етапі у людей зрілого віку вже $€$ розуміння того, що для досягнення особистих цілей необхідно встановлювати контакт з оточуючими, а жадібній людині це робити набагато складніше.

Також респондентам пропонувалося оцінити необхідність жадібності за шкалою від 0 до 10, де 0 - ця риса не є важливою, заважає жити; 10 - це необхідна риса, що покращує життя людей. Отримані дані графічно представлено на рисунку 3.

Відповідно до розподілу оцінок необхідності жадібності у житті, відображених на рис. 3, можемо констатувати, що більша частина респондентів юнацького віку $(53,32 \%)$ вважають ії необхідною на середньому рівні, оцінюючи її на 4,5 бала із 10 можливих. На нашу думку, це можна пояснити тим, що всі респонденти юнацького віку, навчаючись на денній формі спеціальності 053 «Психологія», з першого курсу отримують різноманітні практичні завдання, спрямовані на розвиток критичного мислення та вироблення навичок саморефлексії. Окрім того, період юнацького віку це період розвитку не тільки психічних функцій та процесів, але й період інтенсивного фор-

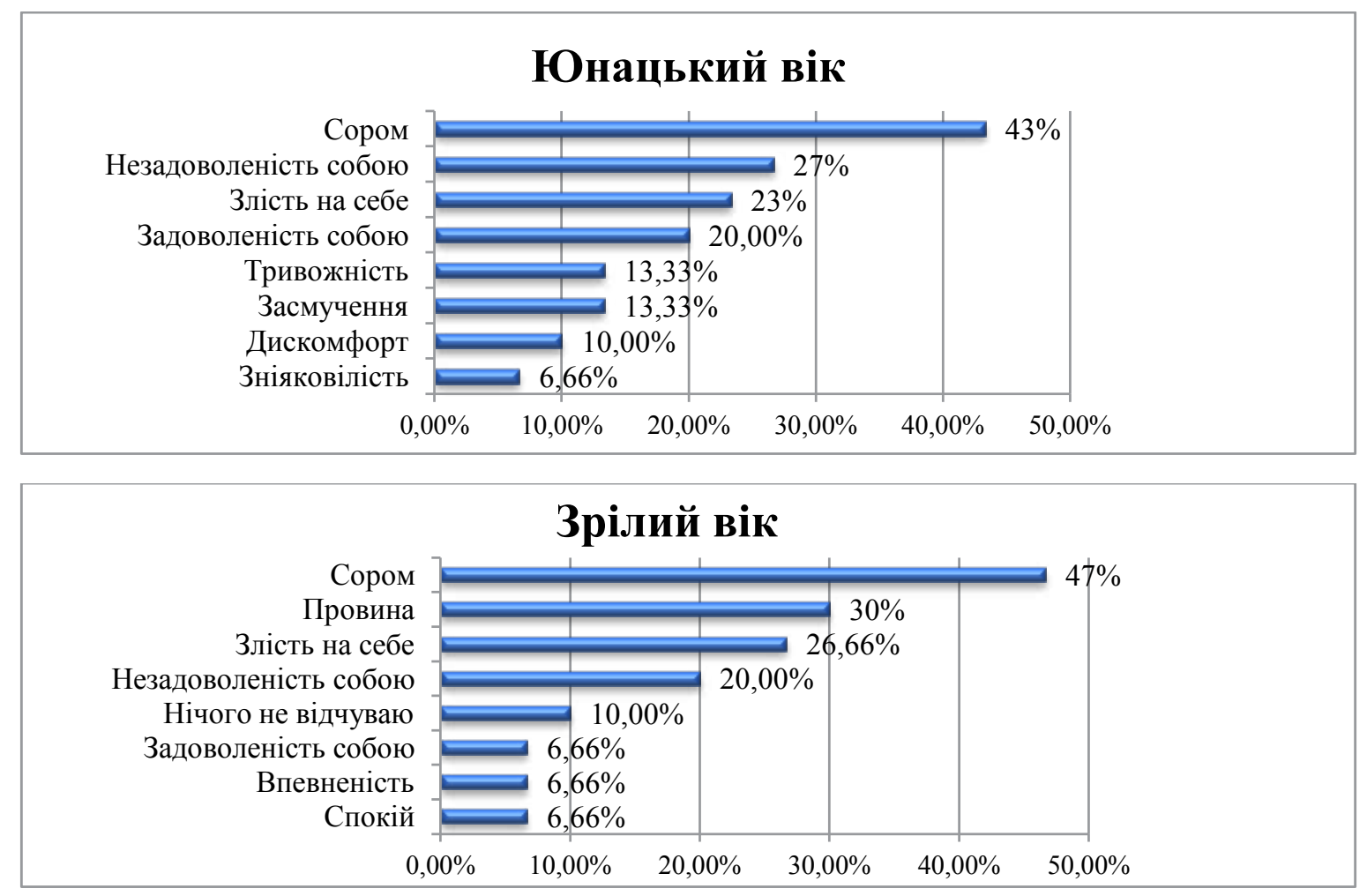

Рис. 4. Розподіл відповідей досліджуваних груп респондентів щодо виразності почуттів у разі прояву жадібності як особистісної риси 
мування системи цінностей. На наш погляд, усе це сприяє усвідомленню наявності та прийняттю проявів жадібності як риси особистості у собі та інших.

Серед досліджуваних зрілого віку оцінки значущо відрізняються. Практично половина досліджуваних (49,9\%) цієї групи надала оцінку необхідність жадібності у житті 2,5 бала із 10 можливих. Це свідчить про негативну оцінку цієї риси респондентами зрілого віку та її відторгнення у власних проявах чи проявах інших осіб. Отримані результати

Таблиця 1

Розподіл виразності почуттів у досліджуваних груп респондентів щодо власного прояву жадібності

\begin{tabular}{|l|c|c|c|}
\hline \multicolumn{4}{|c|}{ Почуття } \\
\hline \multicolumn{1}{|c|}{ Юнацький вік } & Відсоток & Зрілий вік & Відсоток \\
\hline Тривожність & $13,33 \%$ & Провина & $30 \%$ \\
\hline Засмучення & $13,33 \%$ & Нічого не відчувають & $10 \%$ \\
\hline Дискомфорт & $10 \%$ & Впевненість & $6,66 \%$ \\
\hline Зніяковілість & $6,66 \%$ & Спокій & $6,66 \%$ \\
\hline
\end{tabular}

Таблиця 2

Розподіл відповідей респондентів юнацького віку щодо фраз, які вживалися у сім’ї, що пов'язані із темою грошей

\begin{tabular}{|c|l|c|}
\hline № & \multicolumn{1}{|c|}{ Фрази } & Відсоток \\
\hline 1 & Гроші з неба не падають & 23 \\
\hline 2 & Кошти треба витрачати з головою & 20 \\
\hline 3 & Хто не працює, той не їсть & 17 \\
\hline 4 & Гроші - як вода & 13 \\
\hline 5 & Гроші для того, щоб їх витрачати & 10 \\
\hline 6 & Не варто вчитися собі відмовляти & 10 \\
\hline 7 & Усіх грошей не заробиш & 7 \\
\hline
\end{tabular}

Розподіл відповідей респондентів зрілого віку щодо фраз, які вживалися у сім'ї,

Таблиця 3 що пов'язані із темою грошей

\begin{tabular}{|c|l|c|}
\hline № & \multicolumn{1}{|c|}{ Фрази } & Відсоток \\
\hline 1 & Необхідно економити & 30 \\
\hline 2 & Гроші легким шляхом не дістаються & 20 \\
\hline 3 & Потрібно більше заробляти & 16 \\
\hline 4 & Для рідних не шкодуй грошей & 10 \\
\hline 5 & Треба почекати, твої забаганки зачекають & 10 \\
\hline 6 & Витрачати гроші лише на необхідне & 7 \\
\hline 7 & Усіх грошей не заробиш & 7 \\
\hline
\end{tabular}

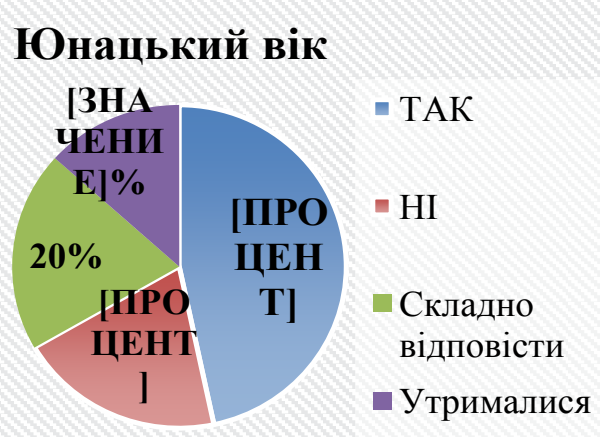

Зрілий вік

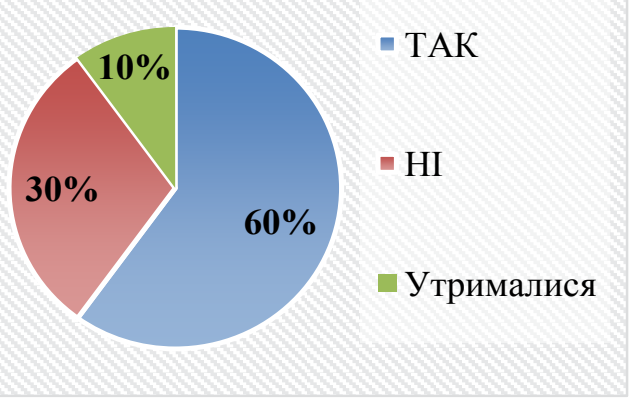

Рис. 5. Розподіл відповідей досліджуваних груп респондентів щодо необхідності корекції жадібності як особистісної риси 
цієї групи ми пояснюємо тим, що у більшості осіб цієї групи жадібність асоціюється із негативними проявами, у тому числі слабкістю і саморуйнуванням. Саме тому більшість респондентів намагаються не проявляти цю рису характеру, використовуючи такі захисні психологічні механізми, як: заперечення, витіснення та пригнічення проявів цієї якості у власному житті.

Також нас цікавила думка респондентів щодо почуттів, які вони відчувають, коли проявляють жадібність. Результати представлено на рисунку 4.

Порівнюючи відповіді осіб двох вікових груп, можна узагальнити, що спільні почуття у разі прояву власної жадібності: сором, незадоволеність собою, злість на себе. Різницею у сприйнятті прояву власної жадібності $€$ те, що в юнацькому віці 20\% серед опитаних мають відчуття задоволеності собою, ніж у зрілому, де цей показник 6,66\%. На нашу думку, це свідчить про необхідність самоствердження у юнацькому віці і відчуття задоволеності собою у тих ситуаціях, коли вдається відстояти своє та зберегти особисті кордони.

Надалі різницю почуттів для зручності буде представлено у таблиці 1.

Також у нашому дослідженні уявлень про жадібність нас цікавили висловлювання, фрази щодо витрат або заробітку грошей, які вживалися у родинах респондентів. Оскільки однією із гіпотез нашого дослідження $є$ те, що одним із факторів формування жадібності як особистісної риси є виховання, в процесі якого із покоління в покоління можуть передаватися родинні послання щодо теми грошей. Отримані результати представлено у таблицях 2, 3.

Відповіді респондентів юнацького віку розподілилися таким чином, що більшість, а саме $73 \%$ родинних послань щодо теми грошей спрямовані на тяжку працю та необхідність заощаджувати. Типовими відповідями є: гроші з неба не падають; кошти треба витрачати з головою; хто не працює, той не їсть; гроші як вода. Значущо менший відсоток (26\%) становили висловлювання іншого семантичного навантаження: гроші - для того, щоб їх витрачати; не варто вчитися обмежувати і відмовляти собі; усіх грошей не заробиш. На нашу думку, подібні фрази налаштовують на життя у моменті «тут і зараз», задоволення власних потреб, легко витрачаючи на це гроші, усвідомленню того, що гроші та грошові накопичення не варті фіксації.

Відповіді респондентів зрілого віку розподілилися таким чином, що більшість, а саме 93\% родинних послань щодо теми грошей спрямовані на необхідність економити, більше працювати і відмовляти у задоволенні собі. Типовими відповідями є: необхідно економити, гроші легким шляхом не дістаються, потрібно більше заробляти, твої забаганки почекають. Значущо менший відсоток (7\%) склали висловлювання іншого семантичного навантаження: усіх грошей не заробиш. На нашу думку, подібні фрази налаштовують на те, що гроші та грошові накопичення у житті не головне.

Серед сімейних послань, які відзначили респонденти юнацького віку, трапляються такі як: не варто вчитися собі відмовляти (10\%), гроші для того, щоб їх витрачати (7\%). У вибірці досліджуваних зрілого віку виокремлюються послання іншого смислового навантаження: для рідних не шкодуй грошей (10\%). Можна констатувати, що родинні послання у групі юнацького віку спрямовують їх на задоволення власних потреб і бажань, а також легке витрачання грошей, на відміну від послань осіб групи зрілого віку, акцент яких спрямований на задоволення потреб інших - рідних для них людей.

Порівнюючи відповіді респондентів обох вікових груп, можна констатувати, що спільними $є$ такі висловлювання: гроші не дістаються легким шляхом, кошти треба витрачати з головою, на необхідне, гроші як вода - потрібно більше заробляти. На нашу думку, подібні родинні послання можуть зумовлювати формування відповідного емоційно-оцінного ставлення до грошей і у респондентів, а також зумовлювати відповідну поведінку щодо грошових витрат та накопичення у власному житті. При цьому зауважимо, що нині це $є$ нашим припущенням, яке буде продовжене у наших подальших дослідженнях.

Наступним ми досліджували у респондентів їхню думку щодо необхідності корекції жадібності як особистісної риси. Графічний розподіл відповідей представлено на рисунку 5.

Як ми бачимо із рисунку 5, більшість респондентів обох груп вважають, що жадібність як особистісна риса потребує корекції. Отже, відповідь на це питання, на нашу думку, відображує негативне ставлення до жадібності як риси характеру. Більшість досліджуваних як зрілого, так і юнацького віку (60\% та 47\% відповідно) все ще свідомо налаштовані корегувати цю рису, якщо не в собі, то в оточуючих.

Висновки 3 проведеного дослідження. Узагальнено, що жадібність визначається як ненаситне прагнення до любові, уваги, їжі, грошей та інших матеріальних чи духовних благ, які у разі накопичення створюють для людини певну психологічну безпеку.

Досліджено, що, на думку респондентів обох вікових груп, жадібність формують такі фактори, як: виховання, невпевненість у собі, життєвий досвід, бідність та економічний стан країни. При цьому, на думку осіб юнацького віку, на формування жадібності ще впливає самотність людини та особистісні риси, такі як: завищена самооцінка, егоцентризм, само- 
любство. Респонденти зрілого віку відносять до факторів, що детермінують жадібність, обмеження у дитинстві.

Досліджено, що респонденти обох вікових груп визначають жадібність як небажання ділитися чимось або втратити щось уже наявне; привласнення собі чогось; наявність невпевненості у собі, у завтрашньому дні. Різниця полягає у тому, що в юнацькому віці жадібність більшою мірою пов'язують із досягненням власного задоволення будь-якими шляхами, незважаючи на оцінку оточуючих.

Виявлено, що респонденти зрілого віку знецінюють необхідність жадібності та оцінюють ії як негативну рису особистості як у власних проявах, так і у проявах інших. Для осіб юнацького віку жадібність $€$ ресурсом, інструментом у встановленні власних кордонів задля задоволення власних потреб.

Узагальнено, що спільними почуттями у разі прояву власної жадібності в осіб двох вікових груп є сором, незадоволеність собою, злість на себе. При цьому зауважимо, що у групі осіб юнацького віку виявлена значущо більша кількість респондентів, які, проявивши жадібність, відчувають задоволення собою, на відміну від зрілого віку, у яких перевалюе почуття провини.

Визначено, що в обох вікових групах панували різні родинні висловлювання щодо теми заробітку та витрат грошей. Спільним лейтмотивом для обох груп $€$ їх спрямованість на необхідність більше накопичувати, важливість економити та пам'ятати, як важко дістаються гроші. При цьому серед сімейних послань у групі юнацького віку виявлені такі, що спрямовують їх на задоволення власних потреб і бажань, а також легке витрачання грошей, на відміну від послань осіб групи зрілого віку, акцент яких спрямований на задоволення потреб інших - рідних для них людей.

З'ясовано, що жадібність як риса особистості, на думку респондентів, потребує корекції. Це можна пояснити негативною гамою почуттів, які виникають у досліджуваних у разі усвідомлення власних проявів жадібності та надання емоційно-негативного навантаження цій рисі й нівелюванню її значущості у житті.

Здійснений нами теоретико-емпіричний аналіз проблеми жадібності як соціально-психологічного феномена виявив різноманітні вектори подальших досліджень. Перспективи подальших досліджень цього напряму ми вбачаємо у більш детальному вивченні жадібності як економічної поведінки, у з'ясуванні феноменології почуттів у разі усвідомлення жадібності, у виявленні різноманітних аспектів проявів жадібності тощо.

\section{ЛIТЕРАТУРА:}

1. Бутко М.П. Економічна психологія. Київ : Центр учбової літератури, 2016. 232 с.

2. Войтика В.І. Психологічний словник. Київ : Вища школа, 1982. 215 с.

3. Фромм. Э. Анатомия человеческой деструктивности. Москва : АСТ, 2009. 547 с.

4. Хорни К. Невротическая личность нашего времени. Самоанализ. Москва : Прогресс-Универс, 1993. 208 c.

5. Шебанова В.І. Феноменологія харчової поведінки у континуумі «норма-патологія». Херсон : ПП Вишемирський В.С., 2016. 612 с.

6. Щербатых Ю.В. Семь смертных грехов или психология порока для верующих и неверующих. Москва : АСТ, 2010. 480 c.

7. Яновська С.Г., Туренко Р.Л., Білоус Н.С., Криворучко С.М., Лютенко Р.А. Психологічні особливості уявлення про жадібність та жадібну людину. Вісник Харківського національного університету ім. В.Н. Каразіна. 2016. № 59. С. 55-58.

8. Akhtar S. Comprehensive Dictionary of Psychoanalysis. Karnac Books. London, 2009. P. 420.

9. Freud S. Charakter und Analerotik. Psychiatrisch - neurologische Wochenschrift, 1908, No. 9. URL: http://freudproject. ua.

10. Rubinstein C. Money \& Self-esteem, relationships, secrecy, envy, satisfaction. Psychology Today. No. 5. 1981. Pp. 24-44. 